\title{
Discourse MARKers IN AN ENGLish AS A FOREIGN LANGUAGE (EFL) CLASSROOM SETTING: A REFLEXIVE STUDY ON TEACHING DISCOURSE
}

\author{
MARCADORES DISCURSIVOS EM SALA DE AULA DE INGLÊS COMO LÍNGUA \\ ESTRANGEIRA (ILE): UM ESTUDO REFLEXIVO SOBRE O DISCURSO \\ DOCENTE
}

DOI: 10.23926/RPD.2526-2149.2020.v5.n2.p723-742.id625

\author{
Alan Tocantins \\ Fernandes \\ Doutorando em Linguística \\ (UNEMAT) \\ alantfernandes@gmail.com
}

\begin{abstract}
This paper is a reflexive teaching study to investigate the use of discourse markers (DMs) in an English as a Foreign Language (EFL) classroom setting with non-native speakers. It is a qualitative and quantitative study that focuses on the teacher's discourse by analysing the occurrences and frequencies in the use of DMs during interaction in class. The corpus was extracted from recordings made during four classes, and later documented through transcriptions. With items selected and categorized in an inventory, it was possible to explain the main functions of the markers used. With the aid of the AntConc $@$ software, it was possible to visualize how the words and phrases of interest appeared in the corpus, in addition to their frequencies. The analysis reveals pragmatic awareness and the use, however restricted, of DMs in the building and organization of classroom interaction by teacher, which contributes to the coherence of his discourse.
\end{abstract}

Keywords: Discourse markers. Reflexive study. Foreign language.

Resumo: Este artigo é um estudo reflexivo de ensino que investiga o uso de marcadores discursivos (MDs) em uma sala de aula de Inglês como Língua Estrangeira (ILE) com falantes não nativos. É um estudo qualitativo e quantitativo que se concentra no discurso do professor, analisando as ocorrências e frequências no uso de MDs durante a interação nas aulas. O corpus foi extraído de gravações realizadas durante quatro aulas, e documentada através de transcrições. Com itens selecionados e categorizados em um inventário, foi possível explicar as principais funções dos marcadores utilizados. Com o auxílio do software AntConc $\odot$, podese visualizar como as palavras e frases de interesse apareceram no corpus, além de suas frequências. A análise revela uma conscientização pragmática e o uso, ainda que com certas restrições, dos MDs na construção e organização da interação em sala de aula pelo professor, o que contribui para a coerência do seu discurso.

Palavras-chave: Marcadores discursivos; Estudo reflexivo; Língua estrangeira. 


\section{INTRODUCTION}

Discourse markers (henceforth DMs) are a feature of oral and written discourse and are widely used to connect pieces of discourses - i.e. what has already been said/written and what is going to be said/written. They are words or short expressions which "usually appear in the beginning of sentences, but can also found in the middle or at the end of utterances" (FRASER, 1990, p.389) to give continuity to the conversation, and share characteristics of lexical, semantic, syntactic, functional or stylistic nature (BRINTON, 1996).

The real time nature of spoken language means that the speaker has to adjust to unplanned and spontaneous situations and may need to use such devices to provide them with the necessary aid to connect ideas, to emphasize or clarify a comment, to orient listeners or get their attention, but also to show attitude towards what is being said, or simply to give the speaker time to think. Paralinguistic features and non-verbal gestures (e.g. body language, gestures, facial expressions, tone or pitch of voice) might be considered as a possible extension of DMs. Nevertheless, such features are not in the scope of this work.

This is a reflexive teaching study which observes a teacher's oral activity and conditions created for foreign language use in the classroom. It does not focus, however, on the classroom contexts from a language acquisition perspective and neither attempts to compare the use of discourse markers to native speakers. It examines the choices and uses of DMs by the teacher, the ways by which they reflect pragmatic awareness and the effects on the ongoing interaction in a controlled environment such as the classroom.

For this research, we analyse data collected in a classroom from a Brazilian institution, in which English as a Foreign Language (EFL) is a reality for both the teacher and the students; we find pragmatic aspects to have great relevance in this setting. By looking at choices and frequency of DMs from a functional perspective we hope to have an indication of the teacher's pragmatic awareness and a better picture of his social dimension of the language.

Thus, as well as investigating the interactional aspects of different types of DMs, their functions and frequency in which they are used in a classroom setting, we attempt to investigate the possible effects they convey by analyzing the linguistically encoded information in their meaning and the kinds of relations the speaker perceives between different parts of the discourse. 


\section{LITERATURE REVIEW}

The use of DMs by non-native teachers of EFL has not been widely explored. The EFL classes usually take place in a setting with contextual characteristics that should be looked at more closely; we find the way in which EFL students and non-native teachers create meaning in such setting - particularly when dealing with critical thinking related tasks, which was the case in this study - quite intriguing. If for native speaker teachers the use of DMs occurs almost automatically, making strategic use of these features may prove to be more difficult for nonnative EFL teachers.

Markers are important features of spoken English and are at the helm of discourse interpretation. As observed by Schiffrin (1987, p. 9), "cohesive devices do not themselves create meaning; they are clues used by speakers and hearers to find the meanings which underlie surface utterances".

The teaching of these specific characteristics of spoken English was addressed by Hilliard (2014). She advocates the recognition and the use of such features of spoken grammar conventions in order to communicate more effectively and encourages teachers to practice and support the practice amongst learners. In addition, the author remarks some pedagogical issues that may arise (e.g. the lack of authentic material).

Walsh (2006, p. 30) argues that "learners have the potential to internalize new language and make it their own; such process is facilitated when their contributions are shaped by teacher interventions". Despite the lack of consensus on the approach teachers should adopt or the extent to which they should teach features of spoken grammar, this practice would allow students to sound more authentic, natural and fluent. The pragmatic aspects of communication could be passed on from teachers to students or among students themselves. Moreover, interpersonal relationship between teachers and students do get affected by the way teachers use such knowledge.

In oral discourse, discourse markers are often phonologically reduced or unstressed (BRINTON, 1996). These apparent empty expressions, but of great importance in orality to establish relationships between topics have also been termed pragmatic markers by Brinton (1996) in some cases due to their function in the language, as it concerns the intention of the speaker. The author highlights the pragmatic functions of DMs to compare them with the grammatical or semantical counterparts. For her, the term pragmatic "better captures the range of functions filled by these items" (1996, p. 30). 
Such approach, however, does not corroborate entirely with what has been proposed by Fraser (1988), who considers DMs to be a subtype of pragmatic marker - commentary markers, more precisely, lexical adjuncts and independent of an already well-formed sentence. Due to this slight lack of consistency in a central definition for DMs and/or pragmatic markers, this study refers to them interchangeably.

The syntactic independence from their environment has been observed by Fraser in other works $(1990 ; 1999 ; 2009)$ and characterized as words and expressions that indicate the relationship between an utterance and the prior discourse. For him, markers "typically signal a relation between the discourse segment which hosts them and the prior discourse segment, perhaps produced by another speaker" (FRASER, 2009, p. 296).

Levinson's work on pragmatics also raised a point in this regard. He highlights words and phrases in English of utterance-initial usages such as but, therefore, in conclusion, to the contrary, still, however, anyway, well, besides, actually, all in all, so, or after all, which "indicate, often in very complex ways, just how the utterance that contains them is a response to, or a continuation of, some portion of the prior discourse" (LEVINSON, 2007, p. 108).

Since they are syntactically separated from the rest of the sentence, the omission of DMs does not bring major impact to what is being said, and the same is true from a semantic viewpoint. Brinton (1996, p. 33) has pointed out that "because of their frequency and oral nature, pragmatic markers are stylistically stigmatized and negatively evaluated, especially in written or formal discourse". She adds that they are "deplored as a sign of dysfluency and carelessness".

Even though DMs are not semantically or syntactically essential in a sentence structure, they have great communicative and interpersonal importance in everyday conversations - both formal and informal. For Brinton (1996, p. 35), "if markers are omitted, the discourse is grammatically acceptable, but would be judged 'unnatural', 'awkward', 'disjointed', 'impolite', 'unfriendly' or 'dogmatic' within the communicative context".

Fraser (1990, p. 390) notes that some DMs "do not create meaning as do other commentary markers such as frankly and amazingly, but only orients the hearer to a particular discourse relationship". In Schiffrin's (1987) viewpoint, DMs display a relation of contents but do not create that relation. Therefore, the structure and meaning of arguments can be preserved even without markers. She elucidates further:

[...] These core meanings do not fluctuate from use to use; rather, what changes is the discourse slot in which they appear - the position of that slot in an exchange, action, and idea structure, in a participation framework, and/or an information state. This 
suggests, then, that markers themselves do not convey social and/or expressive meanings. Rather, markers are situated in very different discourse slots, and it is the utterance within that discourse slot which is interpreted for social and/or expressive meaning (SCHIFFRIN, 1987, p. 318).

In other words, regardless of the meaning belonging to the DM, it has to be compatible with the meanings of the discourse around it.

\subsection{THE ANALYSIS FRAMEWORK}

Since a thorough listing of markers would be impracticable, this study restricted to an adaptation of the inventory of pragmatic markers in Modern English proposed by Brinton (1996), compiled by means of a "partial consensus about the members of the category of pragmatic markers that have received detailed scholarly attention". As a result, a list of 23 frequent linguistic items was generated.

Schubert (2010) investigated the authenticity of teaching materials for EFL in a Brazilian context. In her study, 16 English textbooks published in Brazil between 1992 and 2007 were analyzed in order to determine whether these materials included discursive characteristics or more colloquial language, which could contribute to more spontaneous conversations. She found that there was a concern and a clear effort from some authors and editors of teaching materials to bring the input and pedagogical tasks closer to the real-world. She also observed a clear objective to make the learner become aware of the frequently used linguistic forms in oral speech by native English speakers, which included the use of expressions such as: right, I mean, you know, well, anyway, for example.

In another study carried out in a Brazilian setting, Simões (2004) studied the authenticity in the communication approach by observing classes of EFL students. In her transcripts, DMs similar to those compiled by Brinton (1996) could be found quite regularly: you know, I think, yeah, oklokay, so, now, among others. Thus, despite not including all main items listed by Brinton, both Brazilian studies do corroborate, to a certain extent, the author's selection.

Not all items proposed by Brinton were applicable to the context of the present study either - some were removed and others included arbitrarily. Brinton (1996, p. 31) draws attention to the fact that "there is little agreement among scholars about the inventory of forms to be included in the category of pragmatic marker in Modern English". She adds that "most scholars simply list representative examples".

The detailed qualitative inspection of the corpus, for instance, is of great importance in detecting regularities and frequent patterns in the data, but also to interpret closely the speaker's use of a certain lexical items. An illustration of this is the use of the item like - a verb, a 
preposition or even a noun -, but its role as a hedge, therefore not based on semantic meaning or grammatical status, helps bring flow into the speech, with meaning and purpose. This analysis would not be possible without a qualitative approach.

On the other hand, the quantitative analysis is essential to bring to light the frequencies that particular items are used. This enables us to observe the speaker's preferences for the use of one item rather than another. As argued by Schiffrin (1987), multiple options for coherence for both speaker and hearer are always available and these options are neither categorically required nor prohibited. Quantitative analysis, therefore, can allow us to account for what the speaker has opted to use and measure the degree to which a pattern occur.

This study deals with the functional paradigm of DMs in line with Schiffrin (1987), whose model of coherence in talk could also be considered a model of discourse. Her multifunctional model focuses on local coherence, which is "constructed through relations between adjacent units in discourse, but it can be expanded to take into account more global dimensions of coherence" (1987, p. 24).

Following this paradigm, DMs in the present study are classified confirming with the functional headings proposed by Schiffrin. It is noteworthy that any linguistic item could perform more than one function. The four functional categories proposed by the model of coherence are divided as follows:

1. Referential: this function normally conveys a semantic meaning as well as information about how the discourse is sequenced or coordinated by marking what has been said and what is going to be said, but also indicating different relations (cause, contrast, reorientation/digression, alternative etc.) in the discourse; it also helps on the conversational organization.

2. Structural: deals with the sequence in a discourse, but on a transitional level - from one topic to another, as a turn-transition device (e.g. initiating or taking turns, providing responses) or to inform the hearer of how units of discourse are sequenced. They can also be used to continue or summarize topics.

3. Cognitive, which includes the organization of knowledge of individuals and dynamic internal processes (e.g. opinions, intentions, disagreement, comparisons) by which inferences can be made. Also, it can refer to the state in which speaker/hearer "has information about something" - i.e. meta-knowledge, regarding what speakers and hearers know about each other's knowledge; this function also indicates a thinking process (e.g. erm, I think, I guess etc). 
4. Repair/clarification: utterance activities that allow speakers to locate/replace previous information and designate the speaker's intention to reformulate a thought, an idea etc. The nature of this function enables speakers to adjust their orientation to what has been said until the next conversational unit comes up. Schiffrin (1987, p. 74) reminds us that "almost anything that anyone says is a candidate for repair either by the speaker him/herself or by a listener".

Still with regard to the functions of DMs, in addition to the model proposed by Schiffrin, this study also follows the suggestion made by Brinton (1996) on their grouping into two main categories:

1. Interpersonal mode, which expresses attitude, evaluations, judgments, expectations, and demands of the speaker. This mode deals with the nature of the social exchange - i.e., the roles assigned to both the speaker and the hearer.

2. Textual mode, which refers to the ways that the speaker creates cohesive passages of discourse to structure meaning as text, "using language in a way that is relevant to context" (BRINTON, 1996, p. 38).

Thus, in this study, DMs are understood to be lexical items with interpersonal and textual purposes. We agree with Schiffrin (1987) and Brinton (1996) when they assert that the use of markers is optional, and that their removal from an utterance would not greatly alter (if alter at all) its structure or its propositional content. In this view, DMs may be grammatically optional and semantically empty, but they have great pragmatic relevance, with important implications in teaching practices.

\section{METHODOLOGY}

The spoken corpus for the current study was drawn from recording carried out during four lessons, amounting to nearly eight hours of material recorded in total. The collection of data took place in a course of 'Language Development in Academic Contexts', as part of the Inglês Sem Fronteiras (English Without Borders) programme - a Brazilian federal government initiative. The course aimed at improving the confidence and competence of adult students and civil servants linked to the Federal University of Mato Grosso (UFMT) in the use of English in an academic environment.

The group consisted of seven students in total, but in none of the days in which the recordings happened were all the students in class. As the teacher's speech was the object of the research, the camera framed his image only. However, students and teacher (all of them of 
legal age) signed a consent form, which agreed with the study subject(s), the researcher's right to use the image / audio.

The lessons were of conversation, essentially, and covered the following topics:

1. the use of technology in everyday lives and predictions of its use in the future;

2. how society has become dependent on technology;

3. the role of science in space programs and how humanity can benefit from it;

4. the role of welfare in society.

Once all the recording was complete, a selective process was carried out, which focused on the teacher's utterance in class, since this is a reflexive teaching study. The selection, therefore, comprised all utterances performed by the teacher during the four classes, which included instructions, explanations, but also other interactional features such as transitional markers or confirmation checks. Any interaction with students or overlapping by the teacher detected in the recording was considered and documented in the transcripts. Surely, no generalization about classroom interaction could be done based only on four lessons, but it should be emphasized that this was not the purpose of the study.

Conversations can be multidimensional, sometimes overlapping, with ideas shifting very quickly or in an unplanned fashion. The recording and the subsequent transcription of the conversations were, therefore, of paramount importance. In order to study multi-word DMs in a readable corpus, it was necessary to gather an ocular inventory of selected items, followed by the categorization of their content. The written display of the data helped to organize the descriptive categories to be analysed.

Because DMs operate inside and outside sentences, this analysis required proceeding from lexical (or sentential) levels to the levels of the discourse, as suggested by Schiffrin (1987). For this reason, a combination of qualitative and quantitative analysis was required, as we found them to be complementary to each other for this study.

To visualize how words and phrases of interest appeared in the corpus and their frequency, AntConc $(c)$ software was used. It is an easy-to-operate freeware, multiplatform tool for conducting corpus linguistics research. Among many features, it allows word/expression counts for the entire corpus, presenting them in an ordered list, and quickly allowing the most frequent ones to be found. Despite the great aid rendered by AntConc $\odot$ software in counting the items of interest in the corpus and presenting them in an ordered list, the differentiation of discoursal role of individual items were very limited and could not be done automatically by the program. 
The selection of items for this study took into account those which were embedded in the conversation, displaying context-dependent messages and sequential consequences of certain speech acts, for example: conjunctions (if, because, so, but), interjections (oh), exclamation (well), hedges (kind of, like) or aspectual particles (now, just).

In an attempt to apply the multifunctional models proposed by Schiffrin (1987) and Brinton (1996), the number of DMs that appeared in the teacher's discourse are organized and displayed in a table so the use of discourse markers, arranged in an order of frequency in which they occurred can be easily seen. The table also shows the differentiation of discoursal roles of the individual items, as proposed by the abovementioned models. Other tables are also used to organize and display samples for analysis of DMs extracted from the transcripts, highlighting each DM and numbering each utterance, for organization purposes. These are shown in the following section.

\section{Results}

Table 1 presents a multi-functional inventory of DMs used by the teacher in all four classes recorded - students' utterances were not considered for this study.

Table 1 - Frequency of use and functions of discourse markers in the corpus (Total $=5,511$ words)

\begin{tabular}{|l|c|c|l|}
\hline Discourse markers & Frequencv & $\mathbf{\%}$ & \multicolumn{1}{|c|}{ Function } \\
\hline okay & 102 & 1,85 & Structural \\
\hline and & 89 & 1,61 & Referential; Structural \\
\hline so & 81 & 1,47 & Referential; Structural \\
\hline yeah & 51 & 0,93 & Referential; Structural; Cognitive \\
\hline or & 38 & 0,69 & Referential; Structural \\
\hline but & 36 & 0,65 & Referential; Structural \\
\hline because & 24 & 0,44 & Referential; Structural \\
\hline erm & 24 & 0,44 & Cognitive \\
\hline I think & 17 & 0,31 & Cognitive \\
\hline then & 14 & 0,25 & Referential; Structural \\
\hline like & 12 & 0,22 & Cognitive \\
\hline now & 11 & 0,20 & Referential; Structural \\
\hline first/first of all & 09 & 0,16 & Structural \\
\hline right & 07 & 0,13 & Structural \\
\hline well & 06 & 0,11 & Structural; Cognitive \\
\hline kind of & 04 & 0,07 & Cognitive \\
\hline I mean & 03 & 0,05 & Cognitive; Repair/clarification \\
\hline oh & 03 & 0,05 & Cognitive \\
\hline actually & 02 & 0,04 & Repair/clarification \\
\hline great & 02 & 0,04 & Structural \\
\hline you know/y'know & 02 & 0,04 & Cognitive \\
\hline anyway & 01 & 0,02 & Structural \\
\hline the thing is & 01 & 0,02 & Cognitive \\
\hline & & &
\end{tabular}

Source: Author's data

As shown in Table 1, most occurrences of DMs in the classroom setting observed in this study were structural, followed by referential, cognitive and a much less frequent use of 
repair/clarification markers. They fall into the two categories advocated by Brinton (1996), belonging to the "textual" and the "interpersonal" modes of language. Most markers denoted conversational organization, exchange structures (e.g., questions and answers), turn-taking distribution, alternatives, contrasts, but also expressed a response/reaction to the preceding discourse, requested confirmation or understanding from the hearer, among other features.

Surprisingly, the item okay had most entries in the corpus and a close qualitative analysis also revealed its multifunctional use. Items with important roles in the grammatical system (e.g. conjunctions and, or, and but) were expected to top the list, but okay occurred more often in the corpus.

In the tables showing samples for analysis:

$()=$. very short pause $;()=$. short pause $;(.)=$. longer pause

$(n)=$ utterance number, for organizational purposes

Table 2 - Samples for analysis of discourse marker okay.

\begin{tabular}{|l|l|}
\hline (1) & $\begin{array}{l}\text { one paragraph summarizing and justifying your opinion (..) okay (..) providing one example to } \\
\text { support your view }\end{array}$ \\
\hline$(2)$ & okay (.) can we check the answer (?) \\
\hline$(3)$ & okay (.) that costs a lot of money \\
\hline (4) & okay guys (..) sorry to interrupt you there but (..) let's carry on (.) \\
\hline$(5)$ & okay so you're one step ahead (.) \\
\hline
\end{tabular}

Source: Author's data

Okay functions as a signal to approve, accept, declare support and confirm validity of what is being said (3); as a linking device between two phases (1); as a marker of transitions (2); as pre-closing device (5); as a return marker from a temporary departure from the main subject - i.e., digression (4). Schiffrin (1987), Fraser (1990) and Brinton (1996) address the apparent multifunctionality of DMs as they may be used simultaneously in several different ways.

Together with okay, other items such as well and so can also function as pre-closing devices (6) and (7), but also to re-establish a previous topic or start another round of talk (8) and (9).

Table 3 - Samples for analysis of discourse markers well and so

\begin{tabular}{|l|l|}
\hline$(6)$ & well (...) these things (...) they can happen (.) \\
\hline$(7)$ & so (...) there are many cases of crime (.) \\
\hline$(8)$ & well, he is (...) or he was (.) because he's dead (.) unfortunately (.) \\
\hline$(9)$ & so (.) how much do you like technology (?) \\
\hline
\end{tabular}

Source: Author's data

As a DM, however, well, like oh and erm, do not present a semantic meaning or grammatical status. In this regard, Schiffrin $(1987$, p. 64) reminds us that "markers are never 
obligatory", which means that "any utterance preceded by a marker may also have occurred without that marker". The author leaves us with a question of what functions the absence of a marker would also have. One might ask whether the utterances (6) to (9) would sound more natural or authentic without the markers.

What differs the markers well, oh and erm is that while well contributes at an interactional level, oh and erm contributes at a cognitive level - i.e. how knowledge is distributed through the conversation and how certain (or reliable) it is. It is a feature they share with other items such as I think, like and y'know.

I think and erm were the most frequent cognitive DMs in the corpus. Although I think may evoke a certain vagueness (10) to the speech at times, it is an assertive verb (11) which can also be used to draw attention (12).

Table 4 - Samples for analysis of discourse marker I think

\begin{tabular}{|l|l|}
\hline$(10)$ & I think they're just talking. (..) I don't think it's a lecture, it's just a conversation \\
\hline$(11)$ & So as long as I can hear and make notes, that's enough I think \\
\hline$(12)$ & I was not going to tell you, but I think you should know \\
\hline
\end{tabular}

Source: Author's data

Despite not having a specific meaning, erm fills time (13) and allow the speakers get their thoughts together (14), a function that well, like, and even I think also display. They are important communicative and interpersonal functions, which make conversation flow more easily and naturally.

Table 5 - Samples for analysis of discourse marker erm

\begin{tabular}{|l|l|}
\hline (13) & $\begin{array}{l}\text { she's going to say something to support what she's saying ... erm (...) she's going to give some } \\
\text { descriptions of the area where she lives }\end{array}$ \\
\hline$(14)$ & $\begin{array}{l}\text { they have great education but they have the biggest number of prisoners (...) erm (...) in the world } \\
\text { (..) in proportion to the population }\end{array}$ \\
\hline
\end{tabular}

Source: Author's data

Hedges, such as kind of and like, suggest that a segment should be interpreted less literally (15). They can also be used as the speaker searches for a more appropriate expression (16) or an alternative term (17). Like, in particular, appears with approximate numbers (18) but it also common to find this type of marker expressing exaggerations or unusual events (19).

Table 6 - Samples for analysis of discourse marker like and kind of

\begin{tabular}{|l|l|}
\hline$(15)$ & it's a kind of (.) prediction \\
\hline$(16)$ & it's kind of (.) it's something like what this guy did here ok (?) \\
\hline$(17)$ & but concerned can mean like (.) worried for example \\
\hline$(18)$ & let's do this, like, in 2 minutes (?) or maybe just one minute \\
\hline$(19)$ & they're like sixteen or seventeen and they go to prison with adults \\
\hline
\end{tabular}

Source: Author's data 
One of the most versatile and widely applicable DM in the corpus is yeah, with 51 hits. Yeah presents a clear interpersonal function, as many of its occurrence expresses acknowledgment as a response (20), signal the speaker's (here, the hearer in the interaction) attention (21), the recognition of familiar information (22) and the receipt of new information (23). Yeah shows cooperation in the talk by instigate the hearer to attest to that knowledge (24) or encourage them to continue (25). Yeah is used by the speaker as a reaction marker which also has the interpersonal function of conveying agreement (26).

Table 7 - Samples for analysis of discourse marker yeah. $(\mathrm{S}=$ student; $\mathrm{T}=$ teacher $)$

\begin{tabular}{|l|l|}
\hline$(20)$ & $\begin{array}{l}\mathrm{S}_{4}: \text { Was he was criticized (?) } \\
\text { T: Yeah, another author criticized him (.) }\end{array}$ \\
\hline$(21)$ & $\begin{array}{l}\mathrm{S}_{1}: \text { I agree with that completely } \\
\text { T: Yeah (?) }\end{array}$ \\
\hline$(22)$ & $\ldots$ because criminals will always exist yeah (?) \\
\hline$(23)$ & $\begin{array}{l}\mathrm{S}_{1}: \text { the things we have today, all this technology (..) and they don't see where the physics is, where } \\
\text { mathematics is there ... they don't see that ... this is a really big problem } \\
\text { T: Yeah }\end{array}$ \\
\hline$(24)$ & it's interesting that he made all those predictions yeah (?) \\
\hline$(25)$ & $\begin{array}{l}\mathrm{S}_{1}: \text { Maybe it is interesting to make a small test, because I had problems with a small presentation } \\
\text { a few years ago (...) } \\
\text { T: Yeah (?) } \\
\mathrm{S}_{1}: \text { The sound was not so good }\end{array}$ \\
\hline$(26)$ & $\begin{array}{l}\mathrm{S}_{3}: \text { but there are more (...) letters than numbers } \\
\text { T: yeah (.) yeah (...) we have eight letters and we have six numbers }\end{array}$ \\
\hline
\end{tabular}

Source: Author's data

Like yeah, y'know can be a marker of meta-knowledge for both the speaker and the hearer, indicating their familiarity with a background information in particular (27) and what is generally known/common sense (28). As for the thing is (29), they can mark new knowledge, not shared with the listener before, or be used to emphasize such knowledge.

Table 8 - Samples for analysis of discourse marker y'know and the thing is

\begin{tabular}{|l|l|}
\hline$(27)$ & not probable (...) not possible (..) y'know (...) unlikelihood \\
\hline$(28)$ & Carl Sagan said this in the late 80 s (.) so he said this (...) y'know (..) more than 30 years ago \\
\hline$(29)$ & $\begin{array}{l}\text { ok (...) that's fine (...) but look (...) the thing is (...) if you say probably (...) you're making a } \\
\text { prediction }\end{array}$ \\
\hline
\end{tabular}

Source: Author's data

Fraser (1988; 1990) and Brinton (1996) point out that phrases, sentence fragments and clauses can also be included among the class of DMs, which contribute to the heterogeneous set of forms which are difficult to place within a traditional category. Phrasal chunks such as $y$ 'know, the thing is, I mean also serve to mark discourse structures or to act as conversation fillers, giving the speaker time to think about what to say next in real-time conversation. Nevertheless, these should not be considered the only attributes of the aforementioned expressions. 
Schiffrin (1987) remarks that, as well as directing toward gaining hearer involvement in an interaction, $y$ 'know can also be used as an "appeal from speaker to hearer for consensus", or as if seeking for a cooperative effort or an alignment between them, which seems to be the case in (27) and (28). Thus, it contrasts with the thing is (29) and I mean (30), which marks the speaker orientation.

Table 9 - Samples for analysis of discourse marker I mean and actually

\begin{tabular}{|l|l|}
\hline & \multicolumn{1}{|c|}{ Table 9. } \\
\hline$(30)$ & $\begin{array}{l}\text { I mean (...) my name was on the list (...) but it doesn't always work like that (...) I mean (...) they } \\
\text { have to give a name of a teacher but we don't know who is going to be there }\end{array}$ \\
\hline$(31)$ & $\begin{array}{l}\text { we're going to read this text and decide which of these statements is true (...) actually if they are } \\
\text { mentioned in the text or not }\end{array}$ \\
\hline
\end{tabular}

Source: Author's data

Expressions such as I mean and actually appeared to indicate a clarification (30) or rectification (31) of what is being said, which places them into the textual function defended by Brinton (1996). Despite its grammar status as an adverb, actually incorporates here a pragmatic function, used to indicate the relationship of the utterance to the surrounding discourse. Like $y^{\prime}$ know and the thing is, I mean is a lexicalized clause. Despite having this feature in common, the expression the thing is indicates that an additional information is coming, whereas I mean indicates a paraphrase or modification of a past utterance, and $y^{\prime} k n o w$ could indicate both prior or upcoming utterances.

Schiffrin (1987, p. 324-325) compares the use of I mean and y'know, and explains that "I mean targets a speaker, since it marks the speaker's orientation to an utterance, and prior text, since it in some way continues the meaning already presented in the text". She adds that $y^{\prime}$ know, on the other hand, "targets both a speaker and a hearer since it opens an interactive focus on speaker-provided information".

Several markers from the list can stand out for their semantic and grammatical characteristics. This is case of items such as now, then, because, and, but, or, and so. The deictic meaning of temporal adverbs now and then influences their use on several different discourse planes (SCHIFFRIN, 1987) - i.e. distal and proximal properties, respectively. There may be a thin line between the categories of adverbs and discourse markers and, therefore, a closer look into the discourse context is essential, confirming the fundamental importance of qualitative analysis of the corpus.

As a DM, now places the utterance closer to the speaker's space and time (32), and mark a transition in topic (33). Schiffrin (1987) observes that, in interpersonal arguments, now also 
focuses attention on the speaker's next move (33), as a contrast with what preceded, and denotes the speaker's progression through a discourse, directing it to what is coming next at the same time it puts the speaker in a position of control in the talk (34). She adds that, "in some discourse, now may actually mark a three-part shift - in idea structure, orientation and participant footing” (SCHIFFRIN, 1997, p. 244).

In a textual function, then creates a link to a prior discourse time (35) but also signals that the following event is caused or influenced by the situation which precedes. In the occurrences in the corpus, then indicates continuity (36), marks a temporal connection (37) and sequential dependence on the discourse (38).

Table 10 - Samples for analysis of discourse marker now and then

\begin{tabular}{|l|l|}
\hline$(32)$ & we are using identity cards now (.) and everything \\
\hline$(33)$ & two sentences were not used, right (?) now, how about the ... 'The discovery of the future' (?) \\
\hline$(34)$ & $\begin{array}{l}\text { now (..) you're going to write one very short paragraph (...) one paragraph summarizing and } \\
\text { justifying your opinion }\end{array}$ \\
\hline$(35)$ & $\ldots$ of course (.) then (.) people didn't know more about science and technology \\
\hline$(36)$ & and then we're going to read this text \\
\hline$(37)$ & it was a while ago ... and the reporter asked her if she had a message for her sister then \\
\hline$(38)$ & but then if you use it as an adjective you say voluntary \\
\hline
\end{tabular}

Source: Author's data

Schiffrin (1987) uses now and then to highlight the difficulty to differentiate adverbs from markers in actual use. In the case of then, it is particularly difficult because, according to the author, it is not clear whether these two functions are totally distinct. For her, both adverbial and marker use of then are sequentially dependent and relates to prior and upcoming talk. In addition, the anaphoric nature of the adverbial then displays a temporal relationship between two linguistic events internal to the discourse (35) and (37), whereas marker then displays this relationship not only between linguistic events, but between warrants and inferences, and actions (36) and (38).

With regard to the other items with semantic and grammatic properties mentioned above, and, but, or, because and so occurred with considerable frequency in the corpus. Because of their properties, they are important contributors to the discourse, with different pragmatic use. Although the conjunction and had most entries in the corpus its use was limited to showing continuity (39), adding new information (40) and turn taking (41).

Functioning as a counterpart of and in coordinating the discourse, but marks a contrasting action. In the corpus, the entries express contrast in ideas (42), in interaction conditions (43), but also in topic shifting (44). Another discourse coordinator is or, with regular entries, used to provide a two-way choice to the hearer. These options can inclusive (45) or 
exclusive (46 and 47). That is, in the first, one does not exclude the other whereas in the second it does.

Table 11 - Samples for analysis of discourse marker and, but and or

\begin{tabular}{|l|l|}
\hline (39) & $\begin{array}{l}\text { we live in a society dependent on science and technology ... and hardly anyone knows anything } \\
\text { about science and technology }\end{array}$ \\
\hline$(40)$ & $\ldots$ and those who survive they become (..) expert criminals \\
\hline$(41)$ & and what do overseas students mostly have problems with (?) \\
\hline$(42)$ & there's a good possibility (.) but if I say it's highly unlikely (.) it's a very remote possibility \\
\hline$(43)$ & but maybe today people are more interested \\
\hline$(44)$ & but anyway (..) let's go to the four images there \\
\hline$(45)$ & $\ldots$ it's a very remote possibility or probability that something is going to happen \\
\hline$(46)$ & I think he gave a talk or a lecture \\
\hline$(47)$ & if they are mentioned in the text or not \\
\hline
\end{tabular}

Source: Author's data

The grammatical properties of because and so come forward whenever they contribute to the functional and referential organization of the discourse to indicate causal (48) and resultative (49) relations. But both can have pragmatical use in participation structures, presenting support to a position/argument (50) and organizing and maintaining discourse topics (51).

Table 12 - Samples for analysis of discourse marker because and so

\begin{tabular}{|l|l|}
\hline$(48)$ & I can say I don't go to these meetings because I don't fit in \\
\hline$(49)$ & we have eight letters and we have six numbers (..) so two are extra \\
\hline$(50)$ & $\begin{array}{l}\text { do you think this is in a Brazilian context (?) or in general in the world (?) (..) because if you go } \\
\text { to a country like Korea (.) they are very (.) technology oriented (.) }\end{array}$ \\
\hline$(51)$ & okay (..) so here we have some definitions (.) so let's just match the definitions first okay (?) \\
\hline
\end{tabular}

Source: Author's data

For Schiffrin (1987, p. 210), as well as contributing to the idea structure of utterances, because and so could also "mark the relationships between ideas and speaker/hearer inferences based on those ideas, as well as the relationships between speakers' stated motives and actions". However, all occurrences presented in Table 12 show a textual function, as they denote either new or old information (48), mark sequential dependence (49) and (50), and indicate a new topic or a partial shift in topic (51).

Items such as now, then, and, but, so, or, and because have clear grammatical functions (conjunctions, adverbs etc.), and "are often included in the category of DMs if they also serve pragmatic functions" (BRINTON, 1996, p. 34). Such statement corroborates Schiffrin's (1987) view, when she states that DMs are context-dependant and obtain their function through discourse. The author adds that it is not known whether "syntactic distinctions between adverbs and conjunctions are neutralized at discourse levels, or whether syntactic properties remain to differentiate markers from one another in some way." (SCHIFFRIN, 1987, p. 64). 
The syntactic diversity in elements used as markers, as advocated by Brinton and Schiffrin, can also be found in other grammatical sources, such as adjectives (great and right). As DMs, both great and right present organizational functions in conversation, to signal the opening of topics (52 and 53), which also provides a mark of transition similar to that of okay. In addition to that, right have an important interactional role to evoke response/attention (54), which, to some extent, could also signal the closing of a topic.

Table 13 - Samples for analysis of discourse marker great and right

(52) great (.) so before we do the listening (.) this is just a small preparation

(53) right (.) how was the holiday (?)

(54) about his book (.) he said it has no base (.) scientific base (...) inaccurate, right (?)

Source: Author's data

The frequency results displayed in Table 1 and the further samples carried out suggest that DMs constitute a wide range of discourse functions in different categorical levels (referential, structural, cognitive and repair/clarification). Surely, a more in-depth analyses of individual DMs would be highly complementary.

This study, however, sought to identify main characteristics of classroom language uttered by the teacher in a EFL context and, for this purpose, the analysis conducted here contributed to bring to the fore the main functional paradigm that such variety of DMs have in the classroom environment and the possibilities for socio-pragmatic interaction between teacher and students. Further pedagogical issues will be discussed in the next section.

\section{DiscuSSION}

This study aimed at a reflexive intervention by observing a teacher's discourse in the classroom where EFL was the object of study. By the means of video recording, transcription and the subsequent analysis of the frequency and use of DMs in such environment, the present study sought to identify these important features of classroom language uttered by the teacher. Levinson (2007) points out that conversation analysis forces the researcher to focus on the interaction patterns emerging from the data, rather than relying on any preconceived notions which language practitioners may bring to the data.

Not enough attention has been given to pragmatic aspects of language use. Even though language acquisition is not in the scope of the present work, it could be argued that a narrow inventory of options displayed by teacher in class leads to fewer opportunities for students to perceive diversified ways of talking. As discussed in the works of Brinton (1996), Kramsch 
(1986), Nikula (2002), this is mainly due to the directness in which teachers express themselves in classroom interaction.

Nikula (2002) highlights that this could also be a reflection of the institutional context and its position of authority. Kramsch (1986) notes that such controlled nature in the classroom could make it difficult for the development of more authentic or natural communicational skills and eventually affect interpretation and negotiation of intended meanings.

Speakers might also signal pragmatic meanings in other types of situations - e.g. outside classroom settings. Although it is increasingly common for learners to be in contact with other languages through popular culture or social media, classrooms are still very important contexts for the use of language. Furthermore, despite the fact that pragmatic skills require a "natural" context that is very hard to be formally produced in a classroom setting in which English is a foreign language for both the students and the teacher, the use of DMs is still desired, expected to occur, however limited or repetitive.

In the current study, for the building and organization of classroom discourse, the teacher used DMs to: indicate sequences, contrasts, continuity, new information, to signal results and consequences, to draw/keep the attention of hearer and evoke response/participation. Yet, many repetitions of markers occurred (e.g. okay and yeah) in different functions, which does not necessarily mean a limitation in the teacher's repertoire, but as observed by Crible (2018), a case of disfluency.

In the classes observed for this study, textbooks were not used, which allowed us to investigate the use of DMs during classroom interaction, based on an analysis of the teacher's utterance in semi-controlled tasks and, therefore, with a greater freedom to express and improvise. It also allowed us to better understand how interaction occurred, given that all participants were non-native, in addition to examining more closely and describing the language used by an EFL teacher.

After looking at the uses of DMs, their frequency and distribution in the scenario presented in this study, and investigating the possible effects they convey by analyzing the linguistically encoded information in their meaning, it could be observed that the teacher mostly uses DMs to establish relationships between topics - i.e., grammatical units such as and, so, but, or etc. -, but also with a pragmatic function so as to comment or ensure the state of understanding of information being given (okay, yeah, y'know, I mean etc.).

The functions of markers identified in this study, following the two main categories suggested by Brinton (1996), were both textual and interpersonal. While textual functions were 
associated with the construction of discourse coherence (e.g., initiating, closing or repairing discourse, introducing or partially shifting topics, denoting new or old information etc.) interpersonal functions were related to the reactions and responses during the communicative exchange (e.g., checking or demonstrating understanding, continued attention while interacting etc.).

One may argue that coherence in writing is more difficult to sustain than in speech since writers have no nonverbal clues to inform them if they are getting their message across clearly. In other words, in such view, speakers could have an advantage of more easily situating their underlying strategies and communicative intentions. Schiffrin (1987), however, is attentive to the fact that despite having an intuitive feeling about the (in)coherence in a discourse, it is difficult for us to present a principled account for such judgements, or to predict which sequences will be interpreted as coherent. Nonetheless, speakers should be encouraged to display a wider range of elements into the discourse, from making their patterns of coherence more explicit and, perhaps, in the case of teachers, more carefully planned.

Non-native speakers generally have a pragmatic knowledge base in their native language and will find the equivalent in a foreign language to express themselves, though the examination of frequencies and diversity of items used in class showed the pragmatic knowledge and DMs could have been, potentially, better explored. The teacher's pedagogic goals did not specifically involve the introduction and practice of DMs, but all four lessons had a clear interactive approach, which were excellent opportunities to make use of a wider variety of markers.

If the main goal of communicative language teaching is to develop student's abilities to communicate effectively in different contexts, more pragmatic aspects of language use should be brought into focus. Classrooms are, after all, social contexts and provide participants with excellent opportunities to understand, learn and practice pragmatic features of great significance in language. Time for interaction is also crucial if the objective of efficient communication is to be achieved.

One last observation does not concern the use of DMs in class itself, but something that had some effect on the interaction in class. And since this is a reflexive teaching study, we found it worth paying attention to. Judging from the recording and analysis of the transcript from all four classes, long teacher's turns were detected, which compromised the involvement from the students - far from the strongly intended participation of all, in this type of class. Repetitive and extensive use of instructional language with very little (if any) room for 
interaction could also be observed, as well as lots of recapitulation of what had been said and done previously.

\section{FINAL CONSIDERATIONS}

The present study is an attempt to observe the choices made by a teacher with regard to the use of DMs during interaction in the classroom by using qualitative and quantitative approaches. Although we have been able to draw some conclusions, the list of DMs presented here should not be considered comprehensive and definite. In fact, we suggest that a more thorough examination should be carried out, with more time of recording and, perhaps, including paralinguistic features.

We find that not enough research has been done, for instance, on the implications for teaching and learning when it comes to DMs and more light could be shed on such underexplored field. Further studies could include how the use of markers in the classroom influence learners' acquisition of pragmatics in a foreign language, for instance.

The teacher's discourse was selected in the transcript to serve the purpose of analysis to be conducted here. However, the transcript could be continuously revised to display features of interactions missed in the analysis. This could allow new insights that might lead to new investigations.

From a reflexive study viewpoint, it is highly recommended that a teacher themselves becomes aware of the social dimension of the language they choose and use. Within all the options of DMs that could potentially be used in class to convey meaning, a restricted or repeated use of markers could represent, in a long term, a hindrance, however minor, in the teaching/learning process - as if to misspend resources. Equally important is to be aware that the inappropriate use of DMs leads to misunderstandings, difficulties in interpretation.

\section{REFERENCES}

BRINTON, Laurel. Pragmatic Markers in English: Grammaticalization and Discourse Functions. Berlin; New York: Mouton de Gruyter. 1996.

CRIBLE, Ludivine. Discourse Markers and (Dis)fluency: Forms and functions across languages and registers. Amsterdam/Philadelphia: John Benjamins Publishing Company. 2018 .

FRASER, Bruce. An Approach to Discourse Markers. Journal of Pragmatics. North Holland: Elsevier Ltd. v.14, pp. 383-395. 1990. Disponível em: https://www.sciencedirect.com/science/article/abs/pii/037821669090096V. Acesso em: 20 set 2019. 
FRASER, Bruce. Types of English Discourse Markers. Acta Linguistica Hungarica. Hungary. v. 38 (1-4), pp. 19-33. 1988. Disponível em:

https://www.jstor.org/stable/44362602?seq=1. Acesso em: 01 set. 2018.

FRASER, Bruce. What are discourse markers? Journal of Pragmatics. Boston, USA. v. 31, pp. 931-952. 1999. Disponível em:

https://www.sciencedirect.com/science/article/abs/pii/S0378216698001015. Acesso em: 01 jun. 2018.

FRASER, Bruce. An Account of Discourse Markers. International Review of Pragmatics. Boston, USA. v.1, pp. 293-320. 2009. Disponível em:

https://brill.com/view/journals/irp/1/2/article-p293 3.xml?language=em. Acesso em: 15 set. 2019.

KRAMSCH, Claire. From language proficiency to interactional competence. The Modern Language Journal. Chichester, United Kingdom. v. 70, pp. 366-372. 1986. Disponível em: https://onlinelibrary.wiley.com/doi/abs/10.1111/j.1540-4781.1986.tb05291.x. Acesso em: 20 set. 2019.

HILLIARD, Amanda. Spoken Grammar and Its Role in the English Language Classroom. English Teaching Forum. USA. v. 52, no 4, pp. 2-13. 2014. Disponível em: https://eric.ed.gov/?id=EJ1050242. Acesso em: 20 set. 2019.

LEVINSON, Steven. Pragmatics. Cambridge: University Press. 2007.

NIKULA, Tarja. Teacher talk reflecting pragmatic awareness: A look at EFL and contentbased classroom settings. International Pragmatics Association. Budapest, Hungary. v. 12:4, pp. 447-467. 2002. Disponível em: https://www.jbeplatform.com/content/journals/10.1075/prag.12.4.03nik. Acesso em: 01 jun. 2018.

SCHIFFRIN, Deborah. Discourse markers. Cambridge: University Press. 1987.

SCHUBERT, Bianca. A autenticidade do material didático para o ensino de inglês como língua estrangeira. Linguagens e diálogos, v.1, n.2, pp.18-33. 2010. Disponível em: https://docplayer.com.br/2796153-A-autenticidade-do-material-didatico-para-o-ensino-deingles-com-lingua-estrangeira.html. Acesso em: 22 abr. 2020.

SIMÕES, Luciana. Autenticidade e a abordagem comunicativa: reflexões sobre a sala de aula de língua inglesa. 2004. 134 p. Dissertação (Mestrado em Estudos da Linguagem) Universidade Estadual de Londrina-PR. Disponível em:

http://www.bibliotecadigital.uel.br/document/?code=vtls000098034. Acesso em: 22 abr. 2020.

WALSH, Steve. Investigating Classroom Discourse. New York: Routledge. 2006

Recebido em: 20 de fevereiro de 2020.

Aprovado em: 23 de julho de 2020. 